\title{
Empathic Communication Skill Optimization for Minimizing Children's Excessive Use of Gadgets
}

\author{
Andi Tenri Pada Rustham ${ }^{1 *}$, Muhammad Imran Rusadi², Salsa Sakinah ${ }^{3}$, \\ Ailani Kristanti ${ }^{4}$, Fidya Ainun Cholisha ${ }^{5}$ \\ ${ }^{I}$ Department of Psychology, Medical Faculty, Hasanuddin University, Indonesia \\ ${ }^{2}$ Department of Psychology, Medical Faculty, Hasanuddin University, Indonesia \\ ${ }^{3}$ Department of Psychology, Medical Faculty, Hasanuddin University, Indonesia \\ ${ }^{4}$ Department of Psychology, Medical Faculty, Hasanuddin University, Indonesia \\ ${ }^{5}$ Department of Psychology, Medical Faculty, Hasanuddin University, Indonesia \\ *Corresponding author.Email: tenrirustham81@med.unhas.ac.id
}

\begin{abstract}
Excessive use of gadgets can have physiological and psychological impacts on children. Physiologically, it can cause obesity due to lack of movement and radiation exposure. Meanwhile, psychologically, it can cause speech delay and ADHD symptoms. Children also become aggressive and throw a tantrum when their parents take their gadgets. Gadgets should be used for learning purposes and under parental supervision because devices can impact children's development, especially those aged 3-8 years who need parental attention and love in their growth and development. This study aimed to obtain data related to empathic communication skills to reduce children's gadget use frequency. This research method uses a quantitative approach with an Untreated Control Group Design with Dependent Pretest and Posttest Sample. The results concluded that there was a significant difference between the pretest-posttest of the experimental group. Therefore, the application of empathic communication skills on parents effectively reduces the frequency of children's gadget use.
\end{abstract}

Keywords: Empathic Communication, Gadgets, Parents, Children

\section{INTRODUCTION}

In this modern era, human activities are increasing and varied. In reality, individuals who have become parents, both fathers, and mothers, will work to meet the family's needs. There are various kinds of work, and some of them are pretty time-consuming, including time with family, especially children. Parents who are busy working can reduce the intensity of interaction and communication with children and tend to give gadgets to children as entertainment. In Indonesia, in 2017, around 17.5 million people accessed the internet through gadgets. A Report from wartakotalive.com, at least about $70.6 \%$ of parents, allows early childhood to play with gadgets [1]. On another site, Statista states that about $18 \%$ of parents in Indonesia give their children gadgets to keep them calm [2]. This causes early childhood to become addicted to the use of gadgets. Excessive use of devices can have a physiological and psychological impact on children. For example, physiological effects such as obesity due to lack of movement and radiation exposure and psychological effects include speech delay to the appearance of symptoms resembling ADHD [3].

Another impact that children often experience when their gadgets are taken is described in the research [4]. When parents take gadgets from their children, their children will be annoyed, so that children become aggressive and tend to scream. Gadgets should be used for learning purposes and under parental supervision. This is because gadgets 
can impact children's development, especially those aged 3-8 years who need parental attention and love in their growth and development. Child development is negatively affected by gadgets and mothers who work outside the home [5]. Based on this, it can be seen that there is a gap between the current reality and appropriate conditions, including some parents who have not provided sufficient time to accompany their children in using gadgets, are less strict in limiting children's gadget playtime, and do not control the use of gadgets, including the selection of applications and games used by children [6].

According to Bahri [7], parents who communicate with children correctly make children and parents understand each other. So, one of the techniques that can be used to control the use of children's gadgets is empathic communication skills. Empathic communication is an ability that can be learned and developed through specific techniques [8]. Researchers also want to apply this concept in the field of Psychology, especially in child development, so that the results obtained are expected to help reduce the frequency of children's gadget use. Empathic communication is an ability that can be learned and developed through certain techniques [8]. [9] states that empathy is more than just a means of communication. But is a person-to-person relationship were expressing empathy also includes visual, auditory, and tactile communication. However, understanding accompanied by empathy is one crucial factor that shows how well a person communicates with others and shows a person's character who can persuade others about an idea, feel certain things, or encourage certain behaviors to be realized.

In a study conducted [10], empathy has been shown to affect the quality of care by improving doctor-patient relationships and promoting effective communication. This study developed a rating scale to score empathy communication in medical interviews (REM). The scale is designed to score empathy and confrontation in physician-patient interactions. Parents are the closest figures in a child's life. Bronfenbrenner [11] explains that parents are included in the child's microsystem, where interactions strongly influence children.

Meanwhile, Kiare [12] states that the characteristics possessed by parents, such as age, socio-economic status, family structure, and scores, can affect the moral development of children. Thus, as in [13], children's development results from the intervention of parenting strategies. This is because parenting style is related to how children regulate their emotions to generate empathy. [14]. Following research conducted [15], the form of communication in the family affects the development of empathy in children.

Technological sophistication and types of gadgets will affect children's behavior. Positive and negative behaviors may develop depending on what the child sees. The research [16] found a different impact, namely reduced sleep time and decreased academic scores due to lack of focus in class. The use of gadgets makes children more focused on it so that the stimulus to fall asleep is not felt by the child. This results in children not sleeping on time and their sleeping hours changing. Apart from sleeping irregularly, children cannot concentrate in class because of their declining academic scores. The intensity of excessive use of gadgets significantly affects the psychological condition of children. Another impact of excessive use of gadgets for children aged three years, namely children whining if their gadgets are taken. Research [4] explains that Children will show irritating behavior when something is bothering them. This happens because children accustomed to using gadgets will have difficulty controlling their emotions. As a result, children become dependent on gadgets.

Meanwhile, among various technological developments today, it is still scarce to find studies that can overcome the gap between realities and conditions regarding the intensity of empathic communication between parents and children. Therefore, the researcher views that this research is necessary and important to do so that it can help parents whose children have experienced problems due to gadgets, both physically and psychologically, by providing empathic communication skills training to reduce the frequency of using gadgets in children. This study aimed to obtain data related to empathic communication skills to reduce the frequency of children's gadget use. This research provides benefits, especially in terms of developmental psychology and parent-child communication, so that gadgets can be reduced. The learning of empathic communication skills that the parents have obtained is also expected to 
strengthen the relationship between parents and children and contribute to science related to empathic communication skills and the use of gadgets in children's psychology.

\section{METHOD}

The research method in this research is quantitative research with an experimental approach. The type of experimental design used in this research is Untreated Control Group Design with Dependent Pretest and Posttest Sample. The research design was carried out by giving a pretest to the subject, then before being given a posttest, an intervention would be given to see if there were different test results between the pretest and posttest (Pratisti \& Yuwono, 2018) [17]. This research was conducted on Sunday, August 15 Sunday, August 22, 2021, through the Zoom Cloud Meetings and Whatsapp applications.

The research instrument was the REM scale which was adapted from the research. The scale adapted in this study is the Rating Scales for the Assessment of Empathic Communication in Medical Interviews (REM). Individuals should understand the feelings and perspectives of others without judging, criticizing, and blaming. The attitude is to listen to people respectfully with a desire to understand their perspective (Miller \& Rollinick, 2002) [18]. Researchers spread the Google Form link containing the REM scale and the use of children's gadgets through social media with the subject criteria Have children aged 3-8 years, and children of respondents use gadgets for more than 1 hour per day outside of online schools.

The data collection technique used in this research is through surveys distributed to research subjects who meet specific requirements following the provisions of this study. The survey was given via a google form link containing certain statements related to the topics discussed in this study. The survey comprises rating scales for empathic communication skill scores in medical interviews (REM). The analysis technique used SPSS 21 program. Data analysis used nonparametric Wilcoxon because the data collected was not much.

\section{RESULT AND DISCUSSION}

Test the hypothesis of the distribution of data using the Wilcoxon technique. The results of the hypothesis test of empathic communication skill optimization as a way to minimize children's excessive use of gadgets showed a value in each group, namely the control group and the experimental group. In the control group, the pretest-posttest had a $\mathrm{z}$-value of -0.184 and a p-value of 0.854 because of the p-value $(0.854)>$ 0.05 , there was no significant difference in the pretestposttest score of the control group. In the pretestposttest, the experimental group has a $\mathrm{z}$-value of 2.032 and a p-value of 0.042 ; because the p-value $(0.042)<0.05$, it is concluded that there is a significant difference between the pretest-posttest of the experimental group [19]. Therefore, the hypothesis states that there is an effect of the effectiveness of the application of empathic communication skills on parents to reduce the frequency of children's gadget use is accepted.

Based on the data obtained from this experiment, it was found that there is an effect of the effectiveness of the application of empathic communication skills on parents to reduce the frequency of children's gadget use. The significance value obtained for the control group is 0.854 and for the experimental group, it is 0.042 . The experimental group contained subjects who were given treatment in the form of socialization of empathic communication skills, while the control group was not given the treatment. The results obtained show that the understanding of empathic communication skills reduces the frequency of using gadgets in children. This is because when communication is applied to children, subjects from the experimental group reported a decrease in the frequency of using gadgets in children.

Given that children spend most of their daily lives with their families, a family is a place that plays a vital role in the success of children's learning. The family is the first community where children interact, and the interaction between parents and children affects the use of children's gadgets. Parents with poor communication skills can lead to alienation or conflict in interpersonal relationships. On the other hand, if parents can accept their children for who they are, they can grow, develop, make constructive changes, learn to solve problems and be better. Psychologically better, healthier, more productive, more creative and able to reach their full potential. Sometimes parents do not realize how important communication with their children is at home. Parents are more concerned with 
making money to meet family needs than considering their children's performance in school.

Communication is a social process in which individuals interpret the meaning of symbols given by other individuals. Hovland [20] states that communication is a verbal stimulus that is delivered to change the behavior of others. Umar \& Ali [21] indicated that empathy is a person's tendency to feel what others do when someone is in someone else's situation. Empathy is putting yourself in someone else's shoes. Based on these two understandings, it is concluded that empathic communication is a delivery of information to individuals by placing themselves based on individual circumstances. This makes individuals think about what symbols to give so that the other person does not feel hurt and can understand.

The results of this study are supported [9] statement regarding empathy which is one of the essential factors that shows how well a person communicates with other individuals, persuades other individuals about an idea, feels certain things, or encourages certain behaviors to be realized which in this case in the form of reducing the frequency of use of gadgets in children. Suchman et al. [22] stated that the essence of empathic communication skill is understanding the patient's feelings by clinicians to feel understood. This can be analogous to a parent who understands the child's feelings. Through feeling understood by parents, children become more obedient and do not vent their frustration or boredom on gadgets. Therefore, children can reduce the frequency of using gadgets because they feel more understood and accompanied by their parents.

\section{CONCLUSION}

During the pandemic, almost all activities carried out by humans use gadgets. Likewise, with teaching and learning activities, especially kindergarten and elementary school children. This study aims to obtain data related to empathic communication skills to reduce the frequency of children's gadget use. The study results stated that the control group did not have a significant difference between pretest-posttest. There was a significant difference between pretestposttest in the experimental group, with a significance value obtained for the control group of 0.854 and the experimental group of 0.042 . Therefore, the hypothesis states that there is an effect of the effectiveness of the application of empathic communication skills on parents to reduce the frequency of children's gadget use is accepted.

\section{REFERENCES}

[1] Baskara, P. (2020, Maret 24). Survei Penggunaan Smartphone Siswa Usia Dini di Lembaga Pendidikan Raudhatul Athfal, Begini Hasilnya. Retrieved Februari 14, 2021, from Wartakotalive.tribunnews.com:

https://wartakota.tribunnews.com/2020/03/24/su rvei-penggunaan-smartphone-siswa-usia-dinidi-lembaga-pendidikan-raudhatuf-athfal-beginihasilnya

[2] Nurhayati, H., \& Wolff. (2020, February 26). Parents' perceptions on giving smartphones to their children Indonesia Q2 2019. Retrieved from Statista: https://www.statista.com/statistics/1100085/ind onesia-parents-perception-on-givingsmartphone-to-their-kids/

[3] Srinahyanti, Wau, Y., Manurung, I., \& Arjani, N. (2019). Influence of Gadget: A Positive and Negative Impact of Smartphone Usage for Early Child.

Aceive.

doi:http://dx.doi.org/10.4108/eai.3-112018.2285692

[4] Sumarni, S., Pertiwi, S., Rukiyah, Andika, W., Astika, R., Abdurrahman, \& Umam, R. (2019). Behavior in Early Childhood (2-3) Years: A Case Study on the Use of Gadgets in Social Environments. International Journal of Innovation, Creativity and Change, 8(8), 384404.

[5] Calorina, L., Pawito, \& Prasetya, H. (2021). The effect of gadget use on child development: A path analysis evidence from Malawi, West Kalimantan. Journal of Maternal and Child Health, 5(1), 110-119.

[6] Setiawati, E., Solihatulmillah, E., \& Cahyono, H. (2019). The effect of gadget on children's social capability. Journal of Physics: Conference Series, 1179(1), 1-6. 
[7] Bahri, H. (2019). Strategi Komunikasi Terhadap Anak Usia Dini. Nuansa, 11(1), 48-56.

[8] Biondi, M., Pasquini, M., \& Tarsitani, L. (2021). Empathy, Normalization and De-escalation: Management of the Agitated Patient in Emergency and Critical Situations. New York: Springer Nature.

[9] Valente, F. (2016). Empathy and communication: a model of empathy development. Journal of New Media and Mass Communication, 3(1), 1-24.

[10] Nicola, J., Demmel, R., \& Hagen, J. (2007). Rating scales for the assessment of empathetic communication in medical interviews (rem): scale development, reliability, and validity. Journal of Clinical Psychology in Medical Settings, 14(4), 367-375.

[11] Santrock, J. W. (2011). Life-span development (13 ${ }^{\text {rd }}$ ed.). Mc-Graw Hill.

[12] Kiare, J. (2015). Influence of Parental Characteristics on Preschool Children's Moral Development in Nairobi Country. Kenya: University of Nairobi.

[13] Sangawi, H., Adams, J., \& Reissland, N. (2015). The effects of parenting styles on behavioral problems in primary school children: A crosscultural review. Asian Social Sciences, 11(22), 171-186.

[14] Gilli, S. (2016). Gender bias in parenting styles and its contribution to gender differences in empathy. South Africa: University of Cape Town.

[15] Vieira, E. (2015). Family communication patterns, sympathy, perspective-taking, and girls' thoughts about interpersonal violence. Journal of Family Violence, 30(5), 607-619.

[16] Hedge, A., Bhandary, M., \& Balraj, K. (2019). Negative Impacts of Electronic Gadgets on School Going Children in Dakshina Kannada District. Journal of Advanced Medical and Dental Sciences Research, 7(11), 66-68. doi:10.21276/jamdsr
[17] Pratisti, W., D., \& Yuwono, S. (2018). Psikologi Eksperimen (Konsep, Teori, dan Aplikasi). Surakarta: Muhammadiyah University Press.

[18] Miller, W. R., \& Rollnick, S. (2002). Motivational interviewing: Preparing people for change ( $2^{\text {nd }}$ ed.). The Guilford Press.

[19] Azwar, S. (2019). Penyusunan Skala Psikologi. Yogyakarta: Pustaka Pelajar.

[20] Mulyana, D. (2010). Ilmu Komunikasi Suatu Pengantar (14 ${ }^{\text {th }}$ ed.). Bandung: PT Remaja Rosdakarya.

[21] Umar, M., \& Ali, A. (1992). Psikologi Umum. Surabaya: Bina Ilmu.

[22] Audi, E., Barson, P., \& Rischin, I. (2008). Empathic Communication Skill in CALD Medical Student Interviews. 23(3). 